\title{
The Supply-side Orientation of the Reform of Ideological and Political Theory Courses in Colleges and Universities
}

\author{
Zhong Chongjian \\ Qilu Polytechnic University (Shandong Academy of Sciences), Jinan Shandong, 250353, China \\ zhongchongjian@126.com
}

Keywords: Ideological and political education reform, supply side oriented curriculum system.

\begin{abstract}
With the reform and opening-up for 40 years, the reform of ideological and political theory course in colleges and universities has undergone three drastic reforms. Summing up its experience is not only the best commemoration of the reform and opening-up, but also for better progress. Standing at the historical highlight of the new era, looking back on the three reforms of the ideological and political theory course in colleges and universities, the supply-side orientation is becoming clearer and clearer. The Party and the government, as the main body of the reform, expect colleges and universities to train qualified personnel for the construction of socialism with Chinese characteristics and provide intellectual support and ideological guarantee for the reform and opening-up. Therefore, this paper combs the brief characteristics of the reform of Ideological and political theory courses in colleges and universities, and explains that the supply-side reform has undergone a change from obscurity to clarity in the past 40 years, thus strengthening the main direction of supply-side reform in the future.
\end{abstract}

\section{Introduction}

In the past 40 years of reform and opening up, the ideological and political theory course in Colleges and universities has undergone three major reforms, involving complex relationships such as the multi-subject needs of society, the state and college students and the requirements of the course itself. The trajectory shows not only what to teach and how to teach, but also what to learn. It also reveals the reform thinking of "who to train, what to train and how to train people". Each reform is a supply-side innovation by the Ministry of Education and colleges and universities in response to the needs of the theory and practice of socialism with Chinese characteristics in different historical stages. Its purpose is to introduce the latest theoretical achievements of the Communist Party of China on the law of human social development, the law of socialist construction and the law of governing into the cultivation of talents in Colleges and universities through reform. To meet the needs of social development for professional and technical personnel, to ensure that the construction of a socialist country with Chinese characteristics for the needs of qualified successors, while meeting the needs of the growth of young people of the times.

\section{The practice of reform and opening has driven the three reform.}

The academic circles have different suggestions on the stages of the development of Ideological and political courses in Colleges and universities. The three-stage division method is mainly based on the implementation of the "85", "98" and "05" schemes. It can well reflect the progress of China's reform and opening up, the degree of Marxism in China and the requirements of the times for personnel training. The driving effect of Ideological and political education reform.

2.1 The "85" plan reflects the party's demand for talents at the beginning of reform and opening up.

With the initiation of reform and opening up and the arrival of the spring of science, coupled with 
the talent gap caused by the 10-year "cultural revolution", there is a huge demand for talents in social development and national construction, and the cultivation of talents mainly depends on themselves. The arduous mission of colleges and universities is beyond exception. One of the most important basic issues on the agenda is "for whom, for what kind of people, and how to train people" in Colleges and universities, in which "for whom to train people" is directional. The "85" plan of Ideological and political education in universities reflects the reflection and answer to this question. In April 1978, the General Office of the Ministry of Education issued the Opinions on Strengthening the Education of Marxist-Leninist Theory in Colleges and Universities, thereby restoring the teaching of Ideological and political theory in Colleges and universities and purposefully correcting the "Left" error in the non-scientific dissemination of Marxist theory among young students since the founding of the People's Republic of China, just as Deng Xiaoping reflected: "We have summed up decades of experience in building socialism. What is socialism? What is Marx? We did not fully understand it in the past. [1] Therefore, at the beginning of reform and opening up, colleges and universities must have a process of restoring the scientific nature of Marxist theory. It is not only the political demand of the Party and the state for college students, but also the professional demand of the economic and social development for college students, or the pursuit of happiness for college students to realize the value of life. It is a matter of the Party, the state, the nation and the state. Major interests of courts and individuals. Since the Twelfth National Congress put forward the theoretical proposition of building socialism with Chinese characteristics, the pace of reform and opening up has accelerated. Some things in the western capitalist environment have brought new challenges to the ideological and political education of College students. Deng Xiaoping emphasized that "in order to specially educate our next generation and the next two generations, we must establish a Communist leader." The lofty ideal of righteousness. We must not allow our young people to be captives of capitalist decadent ideas. [2] In August 1985, the Central Committee of the Communist Party of China issued a Notice on Reforming the Teaching of Ideological and Moral Characters and Political Theory in Schools in order to resolve the ideological and political education challenges that appeared at the beginning of the reform and opening-up. The "85" plan should come into being to strengthen the ideological and Political Education of College students. In the "85" plan, the cultivation of the "four possessions" new people clearly conveys the requirements of the Party, the state and the economic and social development for college students in the process of reform and opening up. It is hoped that college students will take the initiative to integrate the individual ideal struggle with the Party's theoretical innovation in the socialist practical construction.

\subsection{The "98" plan responds to the new stage of reform and opening up to a complicated stage.}

After more than 10 years of reform and opening up, great changes have taken place in the world, the national conditions and the Party's conditions. In the process of Sinicization of Marxism, a series of innovative theories have emerged: socialist market economy, ruling the country by law, ruling the country by morality and development are the first important tasks of ruling and rejuvenating the country. The depth and breadth of theoretical understanding often come from the complexity and profundity of practice. As a matter of fact, with the deepening of reform and opening up, many people are confused by the profound changes in their personal circumstances, such as how to achieve common prosperity in the development of market economy, how to encourage, support and guide the development of private ownership and so on. In addition to the problem of hostile forces using China's development, the artificial creation of resistance to slow down China's development and even the attempt to peacefully evolve China's institutional choices, the domestic and foreign environment of China's reform and opening-up has become complicated. Jiang Zemin said frankly: "In the face of the wrong ideological and political views, we should not ignore, criticize or fight." It is extremely dangerous to allow them to disturb people's minds and our ideology, and it is bound to endanger the stability and unity of the whole country and society. [1] Obviously, before the "98" plan was issued, the reform of Ideological and political course in Colleges and universities not only reflected on countering the trend of capitalist liberalization, but also summarized the experience and lessons of the "85" plan. The key to breaking the situation is to grasp and utilize the law. "Summing up the history 
of our Party for more than 70 years, we can draw an important conclusion. That is, our Party has won the support of the people because it always represents the requirements of the development of China's advanced productive forces and represents the requirements of the development of China's advanced productive forces at all stages of revolution, construction and reform." The orientation of China's advanced culture represents the fundamental interests of the overwhelming majority of the Chinese people, and we will strive unremittingly to realize the fundamental interests of the country and the people by formulating correct lines, principles and policies. Therefore, the "98" plan, the "Regulations on the Course Setting of the Two Courses" and the Opinions on the Implementation of the "Three Represents" in Colleges and Universities, is accompanied by the important thought of "Three Represents". It truly reflects what the Party, the state, the economic and social development and other subjects cultivate in Colleges and Universities under the complicated conditions of China's reform and opening up. How to cultivate people?

\subsection{The "05" program reflects the importance of the ideological and political course in Colleges and universities on the law of reform and opening up.}

Reform and opening-up contain the law of human social development, socialist construction and the law of the Communist Party in power. The scientific concept of development has raised the understanding of the three laws to an unprecedented new level through the innovation of development, people-oriented, comprehensive, coordinated and sustainable development and overall consideration. The strategy of rejuvenating the country with talented people and the strategy of national innovation reflect the demand of social development and national construction for talented people with sound and fast development goals, and increase the attention and investment in training talents in Colleges and universities. "A farsighted nation always pays attention to young people; a farsighted political party always regards young people as an important force to promote historical development and social progress. Youth represents the future and youth creates the future. Only by winning young people can we win the future. [1] '05'program is facing college students who are more active and eager to succeed than ever before in the context of an era of market economy. The contemporary nature of the "05" program is quite different from that of the youth in the "98" program. Therefore, the Opinions on Further Strengthening and Improving Ideological and Political Theory Course in Colleges and Universities issued by the Propaganda Department and the Ministry of Education of the Central Committee of the CPC, namely, the "05" scheme, compared with the "85" scheme and the "98" scheme, its main feature is to pay more attention to the use of laws to solve the problem of "for whom, for whom and how to train" in Colleges and universities. The problem of training people. For example, the construction of the Faculty of colleges and universities, the construction of Marxist theory discipline and the standard Marxist Institute have been successively promulgated. In April 2018, the Ministry of Education issued a notice entitled "Basic Requirements for the Teaching of Ideological and Political Theory Courses in Colleges and Universities in the New Era", which followed the "05" plan and only partially revised the credits of Ideological and Political Courses, further confirming its grasp and utilization of the law and conforming to the main direction of supply-side reform in the new era.

\section{Setting up the curriculum system highlights the supply side reform.}

The ideological and political theory course system in Colleges and universities ultimately solves the problem of supply of ideological education for college students. From Mao Zedong's point of view, "All departments should be responsible for ideological and political work, the Communist Party should be responsible for it, the Youth League should be responsible for it, the government departments in charge should be responsible for it, and the school principals and teachers should be responsible for it." [2] According to the law of social development, teaching and educating people and the law of talent growth, Xi Jinping emphasized that "education should not only transfer knowledge, but also aim at cultivating morality and cultivating people, satisfying people's own development needs, and fulfilling the expectations of society and the state." [3] It reflects that every 
change of the ideological and political course system in Colleges and universities is a supply-side reform because of the needs of students, society and the state and the Party's theoretical innovation.

\subsection{The "85" program system has two steps to establish the task orientation of Ideological and political courses in Colleges and universities.}

The construction of the curriculum system of the "85" program is formed in a special historical environment. Its formation is manifested in two steps. The first step is that the ideological and political course in Colleges and universities is charged with the urgent task of restoring young students'correct understanding of Marxist theory and changing the situation of the lack of basic Marxist theory among college students. The unprovoked debate of Marx's basic viewpoints and methodology has released ideological strength for reform and opening up. In April 1978, according to the Opinions on Strengthening the Education of Marxism-Leninism Theory in Colleges and Universities issued by the Ministry of Education, four courses were offered in Colleges and universities, namely, Dialectical Materialism and Historical Materialism, Political Economics, History of the Communist Party of China and History of the International Communist Movement. From the four courses offered, they are sufficient to convey the intention of the curriculum system: to provide college students with the basic principles of Marxism and the basic struggle history of the Communist Party of China, to restore a correct understanding of Marxism, and to explore for the Communist Party of China the cohesive force of "what is socialism, how to build socialism" . The second step is that the "85" programme system should serve the requirements of the comprehensive structure of the "four talents". The damage caused by the "Cultural Revolution" and the initiation of reform and opening-up put forward urgent and severe demands on the quantity and quality of talents. Deng Xiaoping put forward a new orientation of "being a new Communist with ideals, morality, culture and discipline". The curriculum adjustment of the "85" program obviously responds to this orientation. Task-driven orientation, with "Marxist Principles" instead of "Dialectical Materialism and Historical Materialism" and "Political Economy" and joined the content of "Scientific Socialism"; with "World Political Economy and International Relations" instead of "International Communist Movement History"; with "Chinese Revolutionary History" instead of "International Communist Movement History" "History of the Communist Party of China" and "Legal Basis" courses have been added to highlight the reform and opening up of China's own and socialism, Marxism and the relationship between the outside world and a comprehensive grasp of the reform and opening up for the early training of qualified personnel in line with the needs of the state and society to provide political wisdom.

\subsection{The "98" program system is comprehensively deepened to help the rapid development of reform and opening up.}

Deng Xiaoping's speeches further emancipated the ideology of reform and opening up, and China's economy and society entered a stage of rapid development. Subsequently, China's economic system has undergone profound changes, social structure has undergone profound changes, the pattern of interests after the division and combination of profound adjustments, followed by profound changes in people's ideas, presented in front of people is often a variety of social contradictions and disputes continue to increase. At the same time, China's development has aroused concern in the West. "Over the years, they have been making use of the so-called" human rights", "democracy", "freedom", "nationality", "religion"and the Dalai Lama and Taiwan issues to make trouble for us. They also collaborate with so-called "civil movement" elements in exile and enemies in our country in an attempt to act together. Therefore, the ideological and political course in Colleges and universities shoulders the long-term and complicated mission of struggling against the infiltration and subversion of various hostile forces at home and abroad, so that college students can understand the world, the national conditions and the Party's conditions, so that they can strengthen their socialist beliefs, carry forward national virtues and have a sense of mission in the course of reform and opening up, so as to resolve the various kinds of problems they face. Risk. The curriculum system of the "98" program strengthens the systematic education of college students'ideology, positioning the teaching of 
Ideological and political course as the main channel and position of College Students' ideological and political education, and dividing "Marxist Principles" into "Marxist Philosophy Principles" and "Marxist Political and Economic Principles". Cheng insisted on educating and disseminating Marxist theory to college students in order to solve the problem of what banner to raise in the reform and opening up; replaced the teaching of "Chinese Revolutionary History" with "Introduction to Mao Zedong Thought" and added "Introduction to Deng Xiaoping Theory" to solve the problem of China's own way of reform and opening up; and "Contemporary China" World Economy and Politics and Situation and Policy have basically maintained the settings since the "85" plan, which is not only the inheritance and Inspiration of the basic policy of reform and opening up, but also the theoretical solution to satisfy college students'understanding of the world. At the same time, the governance concept of combining the rule of law with the rule of virtue is also reflected in the "Ideological and Moral Cultivation" and "Moral Cultivation". The curriculum of legal basis. In a word, as many as eight courses are set up to express the expectations and requirements for college students in the high-speed development stage of reform and opening up.

\section{3 "05" program aims to provide high-quality ideological and political education supply.}

Just as China's reform and opening-up from touching the stones to crossing the river to making use of the laws of human social development, socialist construction and the ruling laws of the Communist Party, the ideological and political course in Colleges and universities has also developed to a new stage. "To do a good job of Ideological and political education in Colleges and universities, we should adhere to the combination of education and self-education, political theory education and social reality." We should combine practice with practice, persist in solving ideological problems with solving practical problems, persist in combining education with management, persist in inheriting fine traditions with improving and innovating. [2] The stage of respecting and utilizing the law in the development of Ideological and political education in Colleges and universities, the "05" program curriculum system emerged at the historic moment, and adjusted the original eight courses to four courses: the Outline of Modern and Contemporary History of China, the Outline of Basic Principles of Marxism, the Outline of Mao Zedong Thought and the Theoretical System of Socialism with Chinese Characteristics. And "Ideological and moral cultivation and legal basis". The new curriculum system not only sums up the experience and lessons of Ideological and political course in Colleges and universities, but also integrates the knowledge of basic theory research, discipline construction and teaching reform. It also uses the law to construct an organic whole with each other's abilities and conditions, and strives to elevate the ideological and political course from the simple role of training qualified personnel. To college students who truly love, benefit from life and memorable roles throughout their lives. The pursuit of high quality in the "05" program curriculum system is also reflected in the emphasis on practical teaching. In "Opinions of the State Council of the CPC Central Committee on Further Strengthening and Improving the Ideological and Political Education of College Students" (No. 16, 2004), and "Education Department of the Propaganda Department of the CPC Central Committee on Further Strengthening and Improving the Ideological and Political Theory of Colleges and Universities" The opinions of the course (Education and Social Administration [2005] 5) and the opinions of the Ministry of Education of the Propaganda Department of the Central Committee of the CPC on Further Strengthening and improving the ideological and political theory course in Colleges and universities (Implementation Plan) (Education and Social Administration [2005] 9) all put forward requirements and policy support for the practical teaching of the "05" program curriculum system. The follow-up of practical teaching not only follows the dialectical relationship between practice and theory, but also improves the students'ability to transform theory into practice, and embodies the respect and utilization of the law of Ideological and political education in Colleges and universities. Because of this, after the spirit of the 19th National Congress of the CPC and Xi Jinping's thought of socialism with Chinese characteristics in the new era were put forward, the "05" program curriculum system was adopted in the ideological and political education in Colleges and universities, and the mission of cultivating new people in the era of national rejuvenation was recognized. 


\section{The trend of supply side reform of Ideological and political courses in Colleges and universities in the new era.}

Since the 18th National Congress of the Communist Party of China, our reform and opening to the outside world has expanded with a greater degree of reform and openness. Therefore, China has come closer, more confident and more capable than at any time in history to realize the great recovery of the Chinese nation. The historical orientation of the goal of prosperity, the unprecedented truth confidence, theoretical confidence, institutional confidence and cultural confidence that the Chinese people, including college students, have also gained. The reform and opening up of China as a whole, because of Xi Jinping's new era of socialism with Chinese characteristics, is clearly positioned in the "adherence to quality first, benefit first, to the supply side" Structural reform as the main line, to promote economic development quality change, efficiency change, dynamic change. "The reform of Ideological and political course in Colleges and universities has undoubtedly entered this new stage of change.

First of all, the ideological and political course in Colleges and universities should emphasize the characteristics of the times.

Forty years of reform and opening-up have shaped a new generation of young people in China, especially the college students who entered universities after the Nineteenth National Congress. Most of them are post-00s. They have broad vision, rich imagination and the pluralistic advantages of pursuing the truth, goodness and beauty of human beings. They also have multiple worries of emotional burden, loneliness, reality and fiction. The word "Youth" and "empty nest youth" are also generated by them. It is necessary to observe these new variables and try hard to solve the new problems arising from them in order to reform the ideological and political course in Colleges and Universities under the new situation. The group commonness of the contemporary youth is the result of the comprehensive effect of various policies and measures of reform and opening up in the past 40 years. It triggers a tremendous change in people's working methods, lifestyles and ideas, and triggers a chain reaction of society, families and individuals. This kind of reaction focuses on the youth group, mainly has six aspects of doubts: first, life level doubts, some students'families because of social transformation, family situation has sunk; second, social level doubts, with 100 years of time to achieve the achievements of the developed countries in 200 years, meaning that China's development also in 100 years. In order to solve the difficulties and contradictions that developed countries have only solved in 200 years, socialism with Chinese characteristics has to go through a period of prominent contradictions, with various social problems coming in succession. Third, there are doubts at the policy level. Reform and opening-up is the Party's understanding and utilization of the ruling laws of the Communist Party, the laws of socialist construction, and human society. In the process of development, it is unavoidable that some policies and measures have crossed the boundary of seeking truth from facts and harmed the interests of the masses. Fourthly, doubts on the theoretical level originate from the promotion of Marxist Sinicization practice. It also needs to go back to the practice of persuading the masses and mastering the masses, and the process of persuasion education itself is the process of persuasion. Fifth, the process of explaining doubts; fifth, the network level of doubts, network life has become a part of contemporary youth life, the combination of reality and virtual two worlds has brought about a sense of vulnerability to the reality of the group, they are used to observe and understand the problem through the interplay of network virtual and life reality; sixth, the media generated. Doubts, including movies and TV dramas, public opinion hot spots, entertainment shows, Internet red, QQ, Weixin, trembling voice and so on, constantly change the concept of young people and social ways, so that many young people doubt the traditional education, media doubts and even to achieve Ma Yun doubts: "I have too many historical figures, but also want to see." OK, now we can get to know them through reading. But now I doubt a lot of books, because a lot of books about me are not true, I'm still alive. [1] College students who have given way to the above six attributions put forward doubtful requirements for the reform of the ideological and political course in Colleges and universities. General Secretary Xi pointed out in a pinprick of the tongue: "Ideological and political work in Colleges and universities is actually a process of solving doubts and explaining doubts. On 
the macro level, it is to answer the questions of who trains, what kind of people trains and how to train people. In view, it is a process of answering students'questions about where they should exert themselves in life, who to whom, how to use their heart and what to do. It is also a process of responding to students' real puzzlement in their study of social practice and even in the hot discussion of movies, TV plays and public opinions. [2]

Secondly, ideological and political courses in Colleges and universities should be reborn in Nirvana in the innovation of "thinking politics" and "micro thinking politics". Before entering the university, besides using the network to understand the political, economic and cultural environment of our country, there are also ideological and political education courses offered by middle schools. Is the education of the ideological and political course in the university still very loud? The ideological and political education in Colleges and universities lays stress on practical results. Only by innovating the pattern of education can we cultivate talents needed by the state and society. On the one hand, it can adapt to the development trend of "great ideological and political education". Under the background of the new era, the main channel and position of Ideological and political course in Colleges and universities are increasingly dependent on the whole ideological and political work system. The reform of Ideological and political course in the framework of big ideological and political work is more and more clearly emerging. General Secretary Xi requested at the conference on Ideological and political education in Colleges and universities that students should be guided to correctly understand the development trend of the world and China, correctly understand the Chinese characteristics and international comparison, correctly understand the responsibilities and historical missions of the times, correctly understand the lofty aspirations and be down-to-earth, so that students can understand and grasp the history of socialism with Chinese characteristics. Inevitability, consciously integrate the individual ideal pursuit into the cause of the country and the nation, down-to-earth, diligent study, and increase the ability. [2] It is difficult to support the implementation and fulfilment of the requirements of the General Secretary only by the main channel and position of the ideological and political course in Colleges and universities. We should integrate the teaching and reform of the ideological and political course into the whole process of education and teaching, realize the goal and requirement of "educating people in the whole process and in all directions" and work with Party committees, student unions, propaganda departments and counselors at all levels of the school. We should jointly build a new system of Ideological and political education in the ideological and political education system. On the other hand, we should use the trend of science and technology to give the new atmosphere of Ideological and political education in Colleges and universities with "micro thinking and politics". With the emergence of information technology such as Internet + big data, micro culture has springing up rapidly with the characteristics of its fast rhythm and immediacy. "Micro thinking" has also risen quietly in the ideological and political education in Colleges and universities. It has become the focus of Ideological and political reform and innovation. We should seize the interest of students, find a new way of dialogue between teachers and students, meet the growth needs of College students, serve the needs of economic and social development for talents, and respond to the request of the Party and the state to train qualified successors in the new era of Ideological and political education in Colleges and universities.

\section{Summary}

China's reform and opening up 40 years, the realization of Marxism in China's four theoretical breakthroughs, the three reform of Ideological and political courses in Colleges and universities is not only the implementation of the "three into" demand, but also the solution to the demand for social talent, to provide talent support for China's economic and social development. With the advent of Xi Jinping's socialist thought with Chinese characteristics in the new era, China's economic and social development has moved toward high-quality development, and the demand for talents has also been transformed into outstanding talents. In this context, through the reform of Ideological and political education in Colleges and universities to provide quality education, so that college students in China's great social change, grasp the direction of social and national development, and deeply understand 
that the construction of socialism with Chinese characteristics "is not a simple continuation of our country's history and culture, not a simple application of Marxist classical writers set up The model of thinking is neither a reprint of the socialist practice of other countries nor a reprint of the development of modernization abroad. [1] As a result, college students take the initiative to integrate the pursuit of life into the great rejuvenation of the Chinese nation, and the ideological and political lessons in Colleges and universities have also realized the magnificent transformation that makes students truly like, benefit for life and unforgettable.

\section{Acknowledgements}

This paper is the result of the stage research of the undergraduate teaching and research project Z2016M019 in Shandong Province, "Research on Innovation and Development of Ideological and Political Theory Course in Colleges and Universities from the Perspective of Communication Science".

\section{References}

[1] The third volume of Deng Xiaoping's selected works, p137, 1993, people's education press.

[2] The third volume of Deng Xiaoping's selected works, p111, 1993, people's education press.

[3] The third volume of Jiang Zemin's anthology, 2006 edition of the people's publishing house, p88.

[4] The third volume of Jiang Zemin's anthology, 2006 edition of the people's publishing house, p2.

[5] The people's daily, the first edition in June 20, 1998.

[6] Mao Zedong collection (seventh volume), people's publishing house, 1999, p226.

[7] Guangming Daily, the first edition in December 9, 2016.

[8] The third volume of Jiang Zemin's anthology, 2006 edition of the people's publishing house, p82.

[9] Hu Jintao. Speech at the National Conference on Strengthening and Improving Ideological and Political Education. People's Daily. Overseas Edition 1, January 19, 2005.

[10] nineteen major reports

[11] see http://www.sohu.com/a/230881066_100125914?_f=index_edunews_0

[12] Xi Jinping's First Comment on Post-95 College Students, People's Daily, 2nd Edition, January 3, 2017.

[13] Xi Jinping, "Putting Ideological and Political Work through the Whole Process of Education and Teaching to Create a New Situation for the Development of Higher Education in China", "Higher Education in China" 14.2016 years, twenty-fourth periods, p6.

[15] People's daily, May 5, 2018, Second Edition. 